\title{
Two Cases of Rare Pancreatic Malignancies
}

\author{
Wissam Hanayneh, ${ }^{1, *}$ Hiral Parekh, ${ }^{1}$ Garrett Fitzpatrick, ${ }^{2}$ Michael Feely, ${ }^{2}$ Thomas J. George, Jr, ${ }^{1}$ and Jason S. Starr ${ }^{3}$
}

\begin{abstract}
Background: Pancreatic adenocarcinoma remains one of the most lethal malignancies with little treatment advancements. Other less common pancreatic cancer histologies have different outcomes and disease course. In this article, we report two cases of rare pancreatic tumors.

Presentation: The first case is a 59-year old, who was undergoing surveillance of a known pancreatic cyst, which eventually enlarged. The mass was resected and pathology revealed undifferentiated carcinoma with osteoclastlike giant cells. The patient did not receive any adjuvant therapy and has had no recurrence. The second case is of a 60-year-old patient who presented with signs and symptoms of pancreatic insufficiency and was found to have clear cell adenocarcinoma of the pancreas. She received neoadjuvant chemoradiotherapy followed by surgical resection without complications.

Conclusion: Our article presents these rare malignancies, which had outcomes that are more encouraging than typical adenocarcinomas. Genomic sequencing can provide more insight into these tumors and potentially provide targets for therapy.
\end{abstract}

Keywords: clear cell; osteoclast-like giant cells; pancreatic cancer; undifferentiated

\section{Introduction}

Pancreatic cancer remains one of the most lethal malignancies with a 5-year overall survival of $8 \%$ for all stages combined. ${ }^{1}$ Even more sobering is the fact that pancreatic ductal adenocarcinoma (PDAC) is projected to be second most common cause of cancer-related death in the United States by $2030 .^{2}$

PDAC is the most common histology of pancreatic cancer (85-90\%). However, several other histologies of pancreatic malignancies have been described. The World Health Organization (WHO) classifies pancreatic malignancies into epithelial and nonepithelial tumors. Histologically, epithelial subtypes include ductal, mucinous, serous, acinar, intraductal, pancreatoblastomas, and solid pseudo-papillary tumors. The nonepithelial tumors largely consist of neuroendocrine tumors. Despite the noted advancements of the field in the management of PDAC, unfortunately, there is a paucity of data on the rare histological subtypes of pancreatic carcinoma. The incidence, prognosis, and therapeutic outcomes of these rarer tumors are not well known and only a few such cases have been reported in the literature. In this report, we describe two cases of rare pancreatic tumors with the following histologies: undifferentiated carcinoma with osteoclastlike giant cells (UCOGC) and PDAC with clear cell features. In addition, we provide a review of the literature of these rare histological subtypes.

\section{Case 1: Undifferentiated carcinoma}

with osteoclast-like giant cells

A 59-year-old female with a history of papillary thyroid cancer (treated with radioactive iodine) was being followed with serial imaging for benign renal and hepatic cysts. At the time of her surveillance, magnetic resonance image (MRI), a simple $1.6 \mathrm{~cm}$ pancreatic cyst

\footnotetext{
Departments of ${ }^{1}$ Medicine and ${ }^{2}$ Pathology, Immunology and Laboratory Medicine, University of Florida, Gainesville, Florida.

${ }^{3}$ Division of Hematology Oncology, Mayo Clinic, Jacksonville, Florida.

*Address correspondence to: Wissam Hanayneh, MD, Department of Medicine, University of Florida, 1600 SW Archer Road, Gainesville, FL 32610, E-mail: wissam.hanayneh@medicine.ufl.edu
}

(C) Wissam Hanayneh et al. 2019; Published by Mary Ann Liebert, Inc. This Open Access article is distributed under the terms of the Creative Commons License (http://creativecommons.org/licenses/by/4.0), which permits unrestricted use, distribution, and reproduction in any medium, provided the original work is properly cited. 


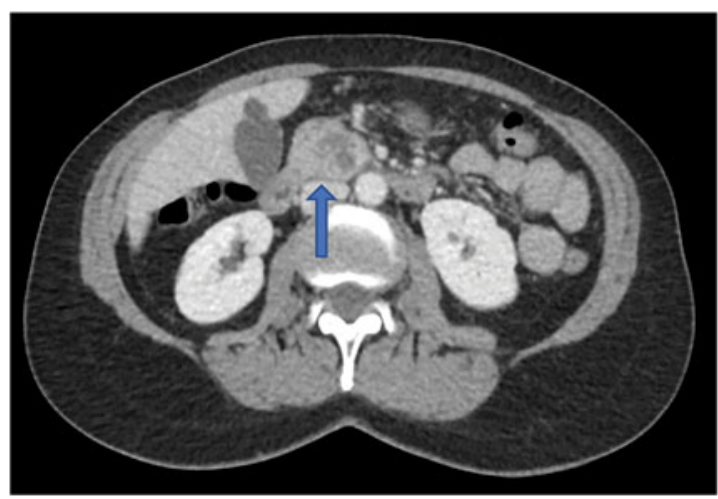

FIG. 1. Axial CT scan of the abdomen in case 1 with intravenous contrast revealing a complex $2.3 \mathrm{~cm}$ pancreatic head lesion (arrow). CT, computed tomography. was noted in the pancreatic head, thought to be consistent with a benign cystadenoma. On repeat MRI 4 years later, the simple cyst had become complex and enlarged. Follow-up with a dedicated pancreatic triple phase computed tomography (CT) was performed, which revealed a $2.3 \mathrm{~cm}$ hypodense mass in the pancreatic head with a $4 \mathrm{~mm}$ enhancing component in the posterior aspect of the lesion with internal septations (Fig. 1). The patient then underwent endoscopic ultrasonography (EUS) with fine needle aspiration (FNA), which showed a high-grade undifferentiated carcinoma. The patient was completely asymptomatic without any laboratory abnormalities aside from a carcinoembryonic antigen (CEA) level of $4.6 \mathrm{ng} / \mathrm{mL}$ (normal $\leq 3 \mathrm{ng} / \mathrm{mL}$ ). The patient's carbohydrate antigen 19-9 (CA 19-9) was within normal limits.

Pancreaticoduodenectomy (Whipple procedure) was performed and the tumor was pathologically staged as
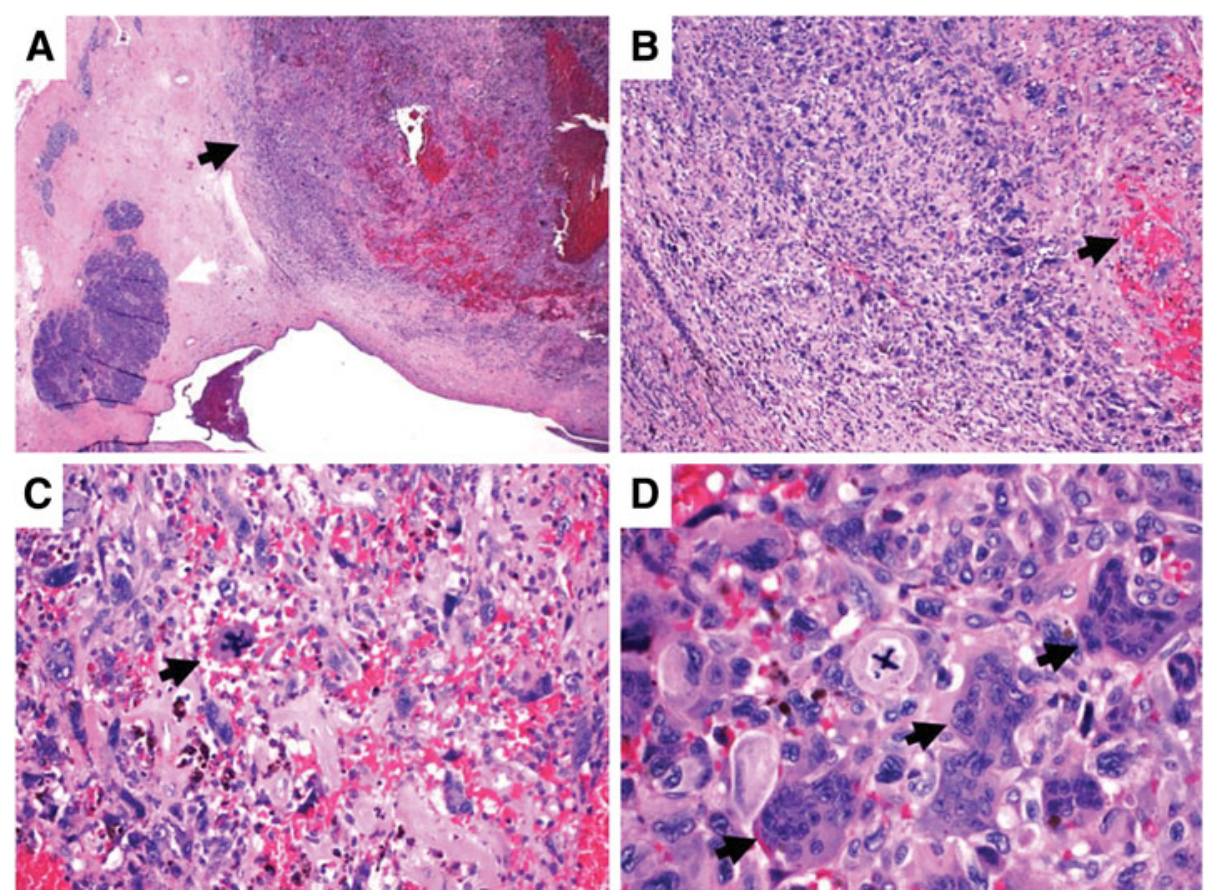

FIG. 2. H\&E-stained sections of UCOGC. (A) Low-power view demonstrating a fairly well-circumscribed tumor nodule surrounded by a rim of desmoplastic stroma (arrow), which abuts adjacent benign pancreas. Hemorrhage is observed within the tumor (arrow), 20x. (B) Central hemorrhage and necrosis give the appearance of a condensation of hyperchromatic nuclei toward the periphery of the nodule, 100×. (C) Multiple mitotic figures, including one bizarre pentapolar mitosis (arrow), are observed within a background of multinucleated giant cells and microscopic hemorrhage. Malignant cells demonstrate marked nuclear pleomorphism and hyperchromasia, 200x. (D) High-power view demonstrating an additional atypical mitotic figure surrounded by multinucleated giant cells (arrows) with a dense cytoplasm. Over 20 distinct nuclei can be observed within a single cell, 400× . $\mathrm{H} \& \mathrm{E}$, hematoxylin and eosin; UCOGC, undifferentiated carcinoma with osteoclast-like giant cells. 
IB (AJCC 8th edition, pT2N0M0). Macroscopically, the tumor was $2.3 \mathrm{~cm}$ in largest diameter. Microscopically, the tumor was well circumscribed with a pushing border, nodularity, and hemorrhage, and was composed of sheets of markedly pleomorphic mononuclear cells with interspersed non-neoplastic osteoclast-like (CD68+) multinucleated giant cells (Fig. 2A). Pleomorphic mononuclear cells stained positive for CK AE1/ AE3 and CAM 5.2 by immunohistochemistry (IHC). Malignant cells were negative for S100, SOX-10, MelanA, and ERG. No conventional ductal adenocarcinoma component was identified. Furthermore, there were foci of hypercellular stroma with an epitheliallined cystic structure suggestive of mucinous cystic neoplasm (MCN), which was now replaced by the malignant cells. This was consistent with UCOGC that developed within an MCN. Seventeen lymph nodes were retrieved and were all negative for malignant cells.

The patient did not receive adjuvant chemotherapy. Over 2 years after surgery, the patient has no evidence of recurrent local or distant disease with a CEA level of $2.8 \mathrm{ng} / \mathrm{mL}$.

\section{Case 2: Clear cell adenocarcinoma}

A 60-year-old female with a medical history significant for type 2 diabetes mellitus, hypertension, and hypothyroidism presented to her gastroenterologist after noting the gradual onset of epigastric abdominal pain radiating to her back. This was associated with a $30 \mathrm{lbs}$ weight loss over a period of a few months. At that time, she reported that she found it more difficult to control her diabetes and required the addition of subcutaneous long-acting insulin to her regimen. Furthermore, she noted foul-smelling loose stools. Her gastroenterologist, concerned for symptoms of pancreatic malignancy and pancreatic insufficiency, performed an endoscopic retrograde cholangiopancreatogram, which showed a common bile duct obstruction. Cytologic brushings were obtained and a sphincterotomy was performed. The results of cytology were negative for malignancy. She continued to have worsening symptoms for another 3 months, so an EUS with FNA was eventually performed, which finally revealed the presence of cells consistent with pancreatic adenocarcinoma.

At that time, her CA 19-9 was elevated to $170 \mathrm{U} / \mathrm{mL}$. A CT scan described a pancreatic head mass measuring $3.6 \mathrm{~cm} \times 3.6 \mathrm{~cm}$, which did not extend inferior to the third part of the duodenum, but it seemed to abut the superior mesenteric vein and possibly the main portal vein as well (Fig. 3). There was dilation of the

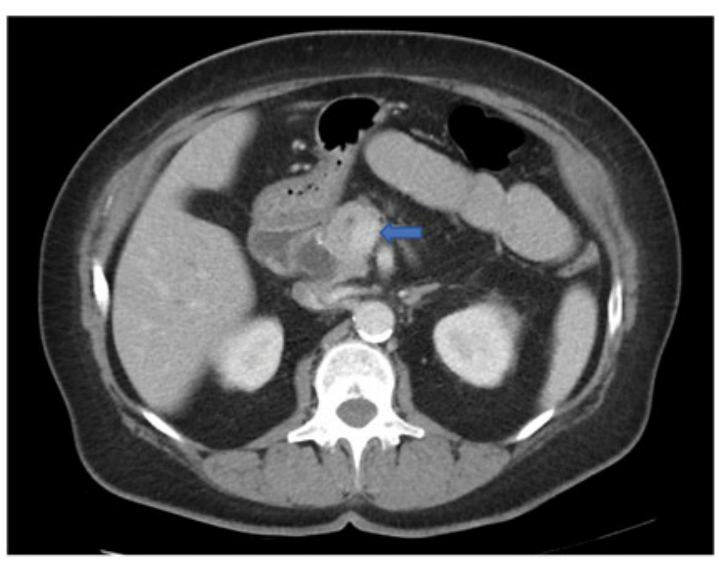

FIG. 3. Axial CT scan of the abdomen in case 2 with intravenous contrast showing an ill-defined pancreatic head mass (arrow) that measures $3.6 \times 3.6 \mathrm{~cm}$. There is associated pancreatic ductal dilatation with abrupt cutoff at the level of the mass. The mass abuts the superior mesenteric vein and there is attenuation of the main portal vein and SMV at the confluence related to the mass. SMV, superior mesenteric vein.

pancreatic, extrahepatic, and intrahepatic ducts. Given these findings, the mass was deemed to be borderline resectable. The decision was made to start neoadjuvant chemoradiotherapy with modified FOLFIRINOX regimen.

Following eight cycles of therapy, a repeat CT scan showed that the mass had shrunk to $2.2 \mathrm{~cm} \times 2.7 \mathrm{~cm}$ and the patient was started on radiation therapy for a total of 28 fractions (5040 cGy) with concurrent capecitabine.

Despite positive radiologic response, the patient's CA 19-9 continued to rise peaking at $422 \mathrm{U} / \mathrm{mL}$ upon completion of all neoadjuvant treatment. The patient successfully underwent a pancreaticoduodenectomy. Pathology revealed a $3.2 \mathrm{~cm}$ tumor with involvement of three of five regional lymph nodes. The tumor was staged as IIB (AJCC 8th edition, ypT2N1M0) with poor treatment response and positive uncinate margin. Interestingly, histology revealed PDAC with clear cell features (Fig. 4).

One of the patient's affected lymph nodes was sent for next-generation sequencing (FoundationOne ${ }^{\circledR} \mathrm{CDx}$ ) testing, which revealed alterations in KRAS G12R (activating mutation), CDKN2A p16INK4a E120* (loss 

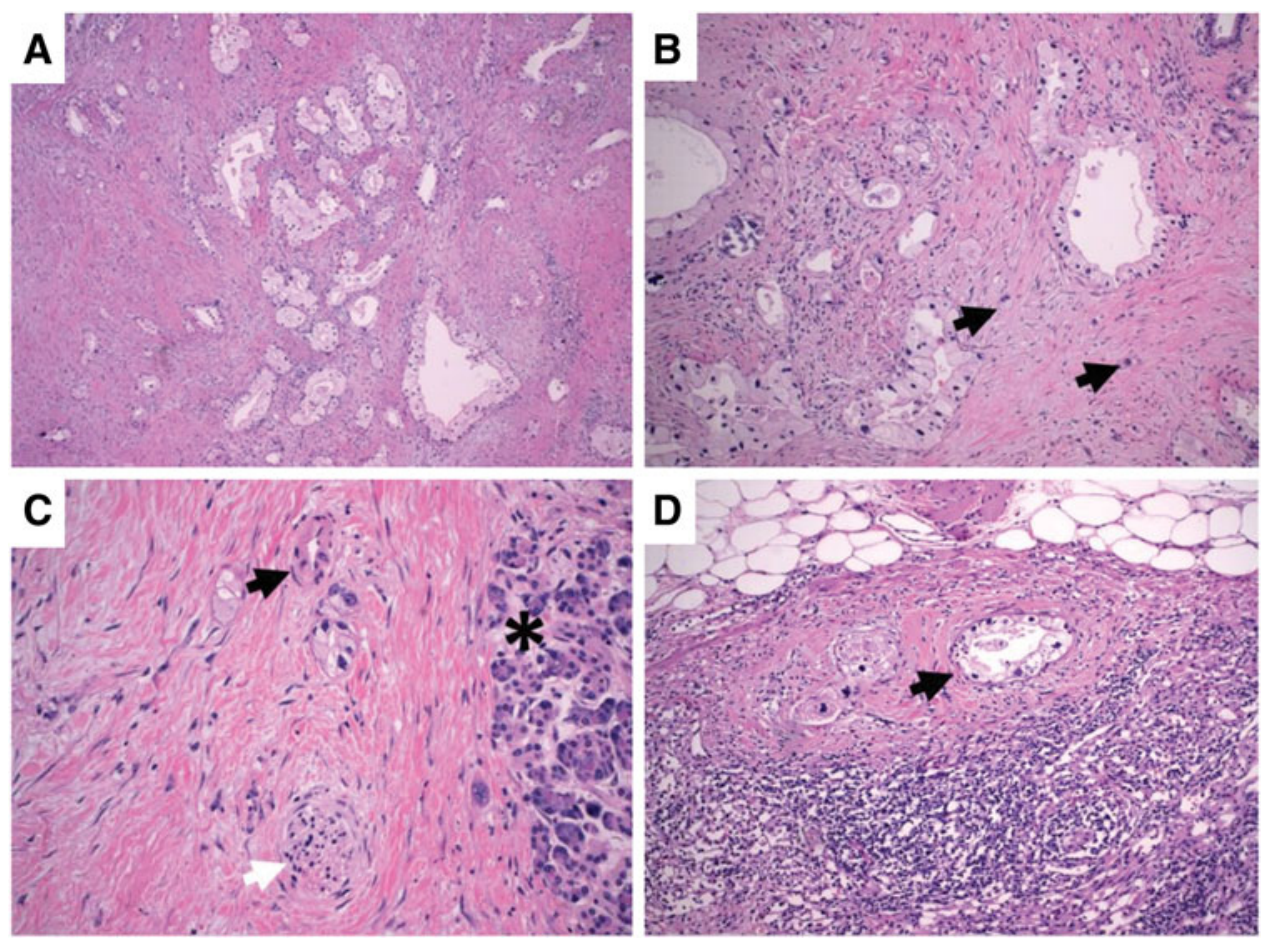

FIG. 4. H\&E-stained sections demonstrating clear cell features. (A) Low-power view demonstrating irregular malignant glands with surrounding desmoplastic tumor stroma. The normal lobular architecture of the pancreas is lost, $5 \times$. (B) Angulated malignant glands are lined by epithelial cells with hyperchromatic basal to central nuclei of varying sizes and variable amounts of foamy to clear cytoplasm (arrows). Single malignant cells are present within the stroma, 100×. (C) Malignant cells are seen invading between an arteriole (black arrow), a nerve (white arrow), and adjacent benign pancreas (asterisk), 100×. (D) Similar histopathologic findings are observed in metastatic tumor glands seen in the subcapsular sinus of a peripancreatic lymph node (arrow), 100x.

of function), and TP53 R273H (loss of function). Patient was placed on surveillance after the surgery. After 6 months, a CT scan showed multiple enlarging mesenteric and retroperitoneal lymph nodes in addition to multiple pulmonary nodules bilaterally, the largest of which measured $5 \mathrm{~mm}$. Given the patient's CKDN2A loss-of-function mutation, the patient was enrolled in a phase I clinical trial utilizing ribociclib (inhibitor of cyclin D1/CDK4 and CDK6), in addition to gemcitabine.

\section{Discussion}

Undifferentiated carcinoma with osteoclast-like giant cells

This tumor was first described in 1968 by Rosai ${ }^{3}$ and was noted to contain two cell populations: osteoclastlike multinucleate giant cells and small mononuclear "stromal cells." It was noted that these tumors were very similar to giant cell tumors (GCTs) of bone, thus termed "giant cell tumor of the pancreas." Electron microscopy, however, revealed that both cell lines differed from GCTs of bone and had features of epithelial cell lines. Therefore, Rosai concluded that these tumors have an epithelial histogenesis. Later, multiple case reports disputed this conclusion when IHC showed staining for mesenchymal markers without features of epithelial cells. ${ }^{4,5}$ Early reports also distinguished two subtypes of GCTs: GCTs with osteoclast-like cells and pleomorphic GCTs ${ }^{6}$ to explain the disparity in the studies. However, it appears that most cases described thereafter have shown that all GCTs contain a mixture of both subtypes. ${ }^{7}$ In 2010 , the WHO grouped them together under the term "undifferentiated carcinoma with osteoclast-like giant cells" (UCOGC). ${ }^{8}$

These tumors are composed of two distinct cell populations: undifferentiated mononuclear neoplastic 
cells, which stain positively for cytokeratins, and nonneoplastic multinucleated osteoclast-like giant cells, which are vimentin and CD68 positive. Histologic features, including a pushing border, tumor nodularity, hemorrhage, and peripheral concentration of giant cells, have been reported. ${ }^{9-11}$

The low proliferative index of the giant cells by $\mathrm{Ki}$ $67^{12,13}$ staining and their lack of driver mutations ${ }^{14}$ are highly suggestive of their benign nature.

Genetically, UCOGC of the pancreas resembles PDAC, with both entities harboring frequent KRAS, ${ }^{10,13,15} \mathrm{TP} 53$, CDKN2A, and SMAD4 mutations. ${ }^{9}$ The exact role of the osteoclast-like giant cells in UCOGC is not known, although they are thought to have phagocytic capabilities. ${ }^{16}$ The mechanism by which the giant cells are recruited to the tumor is also poorly understood. Further investigation is warranted as the osteoclastic giant cells could represent an upregulated immune response and contribute to our understanding of the biology of pancreatic UCOGC and other related tumors.

These tumors can be generally subdivided into two categories: pure osteoclast-like GCTs and those with a component of a more conventional neoplasm. Most often, the more conventional component is a PDAC associated with the GCT, although multiple cases in the setting of intraductal papillary mucinous neoplasm, $\mathrm{MCN},{ }^{17,18}$ high-grade pancreatic intraepithelial neoplasia (PanIN-3), and mucinous cystadenocarcinoma have been reported. ${ }^{10}$ The clinical course of these tumors has been variably reported. Early reports associated UCOGC with a dismal prognosis, ${ }^{19}$ although recent case series support a favorable prognosis with a 5-year overall survival rate of $59.1 \%$ versus $15.7 \%$ in PDAC following resection..$^{10,20}$ The prognosis is especially favorable when tumors are of the pure UCOGC type and lack a conventional ductal adenocarcinoma component. ${ }^{9,21}$ As noted by Muraki et al., the correlation between increased survival and more predominant osteoclastic morphology raises the possibility that the presence of giant cells may represent a strong antitumor immune response to a conventional PDAC. ${ }^{10}$

The paucity of evidence leads to difficulty in determining the optimal multidisciplinary therapeutic approach to this rare malignancy. Surgical en-bloc resection is considered the first line of treatment for localized disease; however, the role of adjuvant chemotherapy is unclear. For the advanced stage and unresectable disease, given the epithelial origin of the mononuclear neoplastic cells, it may be reasonable to consider chemotherapy agents such as gemcitabine for palliation. ${ }^{22}$

Our case displays histologic, immunohistochemical, and clinical features consistent with UCOGC of the pancreas. After multidisciplinary management discussion, given the patient's early-stage disease and lack of data to support adjuvant therapy, the patient was placed on observation due to complete resection and remains disease free 2 years after surgery.

\section{Clear cell carcinoma}

Clear cell morphology is seen in diverse solid malignancies. Metastatic renal clear cell carcinoma can present in the pancreas as late as a decade later. ${ }^{23}$ Furthermore, certain pancreatic tumors such as islet cell tumor, solid and cystic tumors, ${ }^{24,25}$ and perivascular epithelioid cell (sugar) tumors ${ }^{26}$ can have clear cell components to them. However, primary clear cell pancreatic carcinoma remains exceedingly rare. Literature review yielded around 10 case reports describing this rare histology, ${ }^{27-37}$ with the very first case described on autopsy in $1980,{ }^{33}$ see Table 1 for a summary of all published English language case reports.

The tumor has been shown to arise in any part of the pancreas and the literature reports more cases in males. All previous cases reported elevation of CA 19-9 on presentation, indicating a ductal origin.

On IHC, clear cells are typically negative for acinar (trypsin and chymotrypsin) and neuroendocrine markers (synaptophysin and chromogranin,), but epithelial markers are usually positive, indicating a ductal origin. The similarity of IHC staining patterns between PDAC and clear cell carcinoma makes the distinction challenging and the diagnosis is predicated on the morphological appearance on microscopy. Kim et al. ${ }^{28}$ suggested the use of hepatocyte nuclear factor- $1 \beta$ as a marker to distinguish clear cell carcinomas from their more common ductal counterparts. Furthermore, stronger staining patterns on IHC may translate to worse prognosis. ${ }^{38}$ Perivascular epithelioid cell tumor, "sugar tumor," is another pancreatic tumor with clear cell morphology; however, histologically, the cells are composed of epithelioid cells. IHC is usually negative for epithelial markers and for actin and melanogenesisrelated marker (HMB-45), which differentiates it from clear cell carcinoma. ${ }^{26}$

Our case had a genetic alteration in the K-ras gene at codon 12 similar to two other cases in the literature. ${ }^{29,35}$

The optimal treatment and prognosis of these tumors are unknown. Multiple cases show the recurrence 
Table 1. A Summary of All Published English Language Case Reports

\begin{tabular}{|c|c|c|c|c|c|}
\hline Case & Age, sex & $\begin{array}{c}\text { Clinical } \\
\text { presentation }\end{array}$ & Pathology & Staining profile & Mutations \\
\hline $\begin{array}{l}\text { Cubilla and } \\
\text { Fitzgerald } \\
\text { (1980) }\end{array}$ & Undetermined & Autopsy & NA & Positive for mucin & NA \\
\hline $\begin{array}{l}\text { Urbanski and } \\
\text { Medline } \\
\text { (1982) }\end{array}$ & 57, Male & $\begin{array}{l}\text { Abdominal pain } \\
\text { and diarrhea }\end{array}$ & $\begin{array}{l}\text { Giant cells with abundant } \\
\text { eosinophilic cytoplasm } \\
\text { admixed with malignant } \\
\text { spindle cells interspersed } \\
\text { between large cells with } \\
\text { clear cytoplasm and } \\
\text { hyperchromatic nuclei }\end{array}$ & $\begin{array}{l}\text { Positive for PAS, PASD, and Alcian } \\
\text { green. Negative for oil red } 0\end{array}$ & NA \\
\hline $\begin{array}{l}\text { Kanai et al. } \\
\text { (1987) }\end{array}$ & 71, Male & $\begin{array}{l}\text { Abdominal and } \\
\text { back pain }\end{array}$ & $\begin{array}{l}\text { Cells with a clear cytoplasm } \\
\text { in a solid and nested pattern }\end{array}$ & $\begin{array}{l}\text { Positive for PAS and Alcian blue. } \\
\text { Negative for sudan III }\end{array}$ & NA \\
\hline $\begin{array}{l}\text { Lüttges et al. } \\
\quad(1998)\end{array}$ & 53, Male & $\begin{array}{l}\text { Abdominal pain, } \\
\text { weight loss, and } \\
\text { jaundice }\end{array}$ & $\begin{array}{l}\text { Large cells with clear } \\
\text { cytoplasm }\end{array}$ & $\begin{array}{l}\text { Positive for PASD, CK-7, 8, 18, 19, } \\
\text { CAM5.2, and p53-DO7. } \\
\text { Negative for vim, pancreatic stone } \\
\text { protein, chromA, syn, serotonin, } \\
\text { PP, alpha-HCG, substance P, } \\
\text { and VIP }\end{array}$ & $\begin{array}{l}\text { K-ras } \\
\text { mutation } \\
\text { codon } 12\end{array}$ \\
\hline Ray et al. (2004) & 75, Male & Incidental & $\begin{array}{l}\text { Pleomorphic cells with clear } \\
\text { cytoplasm and eccentric } \\
\text { and pleomorphic nuclei }\end{array}$ & $\begin{array}{l}\text { Positive for mucin (mucicarmine, } \\
\text { PASD), CK-7, CAM5.2, CEA, NSE, } \\
\text { A1AT } \\
\text { Negative for vim, syn, chromA, p53, } \\
\text { HMB-45, CD10 }\end{array}$ & $\begin{array}{l}\text { K-ras } \\
\text { mutation } \\
\text { codon } 12\end{array}$ \\
\hline $\begin{array}{l}\text { Sasaki et al. } \\
\text { (2004) }\end{array}$ & 61 , Female & $\begin{array}{l}\text { Epigastric pain } \\
\text { and weight loss }\end{array}$ & $\begin{array}{l}\text { Cells with abundant clear } \\
\text { cytoplasm formed in nests } \\
\text { and duct-like structures with } \\
\text { fibrous stroma }\end{array}$ & $\begin{array}{l}\text { Positive for PAS, PASD, CK-8, CK-19, } \\
\text { A1AT, and CA 19-9 } \\
\text { Negative for CEA, NSE, chromA, syn, } \\
\text { insulin, glucagon, somatostatin, } \\
\text { gastric, trypsin, and HMB-45 }\end{array}$ & $\begin{array}{l}\text { No K-ras } \\
\text { mutation } \\
\text { detected }\end{array}$ \\
\hline $\begin{array}{l}\text { Batoroev and } \\
\text { Nguyen } \\
\text { (2005) }\end{array}$ & 60 , Male & $\begin{array}{l}\text { Epigastric } \\
\text { discomfort }\end{array}$ & $\begin{array}{l}\text { Malignant cells with abundant } \\
\text { clear cytoplasm and } \\
\text { pleomorphic nuclei }\end{array}$ & $\begin{array}{l}\text { Positive for PAS, PASD, } \\
\text { mucicarmine, and CEA } \\
\text { Negative for vim }\end{array}$ & NA \\
\hline Ray et al. (2004) & 46, Male & $\begin{array}{l}\text { LUQ pain and } \\
\text { weight loss }\end{array}$ & $\begin{array}{l}\text { Epithelioid cells with abundant } \\
\text { clear cytoplasm }\end{array}$ & $\begin{array}{l}\text { Positive for pancytokeratin } \\
\text { and CK-7 } \\
\text { Negative for PSA, TTF-1, } \\
\text { thyroglobulin, vim, HMB-45, syn, } \\
\text { and chromA }\end{array}$ & NA \\
\hline $\begin{array}{l}\text { Jamali et al. } \\
\text { (2007) }\end{array}$ & 75, Male & $\begin{array}{l}\text { Abdominal } \\
\text { distension, } \\
\text { dyspepsia, } \\
\text { jaundice, and } \\
\text { weight loss }\end{array}$ & $\begin{array}{l}\text { Clear cells with pleomorphic } \\
\text { nuclei with raisinoid } \\
\text { appearance. Squamous } \\
\text { carcinoma with multinucleated } \\
\text { giant cells. Large cells with } \\
\text { eosinophilic cytoplasm forming } \\
\text { adenocarcinoma }\end{array}$ & Positive for mucin and cytokeratins & NA \\
\hline Lee et al. (2009) & 66 , Female & $\begin{array}{l}\text { Epigastric pain } \\
\text { and weight loss }\end{array}$ & $\begin{array}{l}\text { Round to oval cells with clear } \\
\text { cytoplasm and pleomorphic } \\
\text { nuclei. Rhabdoid cellular } \\
\text { features were seen }\end{array}$ & $\begin{array}{l}\text { Positive for PAS, PASD, } \\
\text { pancytokeratin, CK-7, CEA, } \\
\text { and EMA } \\
\text { Negative for CK-20, chrom, syn, } \\
\text { SMA, and HMB-45 }\end{array}$ & NA \\
\hline $\begin{array}{l}\text { Modi et al. } \\
\quad(2014)\end{array}$ & 75 , Female & $\begin{array}{l}\text { Epigastric pain } \\
\text { and weight loss }\end{array}$ & $\begin{array}{l}\text { Pleomorphic cells with } \\
\text { abundant clear cytoplasm }\end{array}$ & $\begin{array}{l}\text { Positive for vim, CK-7, mucicarmine, } \\
\text { PAS, PASD, CEA, and CA 19-9 } \\
\text { Negative for AFP, CK-20, chrom, syn, } \\
\text { HMB-45, Hep Par 1, and } \\
\text { Glypican } 3\end{array}$ & NA \\
\hline Sun et al. (2018) & 64 , Male & $\begin{array}{l}\text { Epigastric pain } \\
\text { and weight loss }\end{array}$ & $\begin{array}{l}\text { Round to oval cells with abundant } \\
\text { clear cytoplasm arranged in } \\
\text { trabeculae, cords, and tubules. } \\
\text { Pleomorphic nuclei present }\end{array}$ & $\begin{array}{l}\text { Positive for CK-7 } \\
\text { Negative for chromA, syn, } \\
\text { and HNF-1 } \beta\end{array}$ & NA \\
\hline Current case & 60 , Female & $\begin{array}{l}\text { Epigastric pain } \\
\text { and weight loss }\end{array}$ & $\begin{array}{l}\text { Malignant cells with pleomorphic } \\
\text { nuclei and variable amounts of } \\
\text { clear cytoplasm }\end{array}$ & NA & $\begin{array}{l}\text { K-ras } \\
\text { mutation } \\
\text { codon } 12\end{array}$ \\
\hline
\end{tabular}

A1AT, alpha 1 antitrypsin; AFP, alpha fetoprotein; CA 19-9, carbohydrate antigen 19-9; CAM5.2, cytokeratin mouse antibody; CEA, carcinoembryonic antigen; chromA, chromogranin A; CK, cytokeratin; EMA, epithelial membrane antigen; HCG, human chorionic gonadotropin; HMB-45, human melanoma black 45; HNF-1 $\beta$, hepatocyte nuclear factor- $1 \beta$; NSE, neuron-specific enolase; PAS, periodic acid-Schiff; PASD, periodic acid-Schiff with diastase; PP, pancreatic polypeptide; PSA, prostate-specific antigen; SMA, smooth muscle actin; syn, synaptophysin; TTD-1, thyroid transcription factor 1; vim, vimentin; VIP, vasoactive intestinal peptide. 
of the tumor in the form of liver metastasis after surgery. ${ }^{29,38}$ Surgical resection is offered in localized disease, while optimal systemic therapy is unknown in the setting of advanced unresectable disease. Two of the case reports have shown minimal response to 5fluorouracil and gemcitabine chemotherapy. ${ }^{27,38}$

\section{Conclusion}

This report serves to showcase two rare pancreatic malignancies that clinicians can encounter in their practice. Because of the rarity of these tumors, treatment approaches are not guided by clinical trials. Molecular characterization of these tumors with next-generation sequencing, whole-exome analysis, and evaluation of biomarkers for response to immunotherapy (i.e., PDL1, MMR/MSI, and tumor mutational burden) could potentially give us a better understanding of these diseases and help guide treatment.

\section{Author Disclosure Statement}

\section{No competing financial interests exist.}

\section{References}

1. Siegel RL, Miller KD, Jemal A. Cancer statistics, 2018. CA Cancer J Clin. 2018;68:7-30.

2. Rahib L, Smith $B D$, Aizenberg $R$, et al. Projecting cancer incidence and deaths to 2030: the unexpected burden of thyroid, liver, and pancreas cancers in the United States. Cancer Res. 2014;74:2913-2921.

3. Rosai J. Carcinoma of pancreas simulating giant cell tumor of bone. Electron-microscopic evidence of its acinar cell origin. Cancer. 1968;22: 333-344.

4. Robinson L, Damjenov I, Brezina P. Multinucleated giant cell neoplasm of pancreas: light and electron microscopy features. Arch Pathol Lab Med. 1977;101:590-593.

5. Goldberg RD, Fabrizio M, Montag AG. Osteoclast-like giant cell tumors of the pancreas: immunophenotypic similarity to giant cell tumor of bone. Hum Pathol. 1991;22:618-622.

6. Lewandrowski KB, Compton CC. Cell tumor of the pancreas of mixed osteoclastic and pleomorphic cell type: evidence for a histogenetic relationship and mesenchymal differentiation. Hum Pathol 1990;21: 1184-1187.

7. Deckard-Janatpour K, Kragel S, Teplitz RL, et al. Tumors of the pancreas with osteoclast-like and pleomorphic giant cells: an immunohistochemical and ploidy study. Arch Pathol Lab Med. 1998;122:266-272.

8. Hamilton SR, Aaltonen LA. World Health Organization Classification of Tumours Pathology and Genetics. International Agency for Research on Cancer (IARC) Press: Lyon, France; 2000.

9. Luchini C, Pea A, Lionheart G, et al. Pancreatic undifferentiated carcinoma with osteoclast-like giant cells is genetically similar to, but clinically distinct from, conventional ductal adenocarcinoma. J Pathol. 2017; 243:148-154.

10. Muraki T, Reid MD, Basturk $O$, et al. Undifferentiated carcinoma with osteoclastic giant cells of the pancreas: clinicopathological analysis of 38 cases highlights a more protracted clinical course than currently appreciated. Am J Pathol. 2016;40:1203-1216.

11. Sah SK, Li Y, Li Y. Case report undifferentiated carcinoma of the pancreas with osteoclast-like giant cells: a rare case report and review of the literature. Int J Clin Exp Pathol. 2015;8:11785-11791.

12. Dhall D, Klimstra DS. The cellular composition of osteoclastlike giant tumors of the pancreatobiliary tree. Am J Surg Pathol. 2008;32: 335-337.
13. Westra WH, Sturm P, Drillenburg P, et al. K-ras oncogene mutations in osteoclast-like giant cell tumors of the pancreas and liver: genetic evidence to support origin from the duct epithelium. Am J Surg Pathol. 1998;22:1247-1254.

14. Sakai Y, Kupelioglu AALI, Yanagisawa A, et al. Origin of giant cells in osteoclast-like giant cell tumors of the pancreas. Hum Pathol. 2000; 31:1223-1229.

15. Koorstra JBM, Maitra A, Morsink FHM, et al. undifferentiated carcinoma with osteoclastic giant cells (UCOCGC) of the pancreas associated with the Familial Atypical Multiple Mole Melanoma Syndrome (FAMMM). Am J Surg Pathol. 2008;32:1905-1909.

16. Shiozawa M, Imada $\mathrm{T}$, Ishiwa $\mathrm{N}$, et al. Osteoclast-like giant cell tumor of the pancreas. Int J Clin Oncol. 2002;7:376-380.

17. Hirano H, Morita K, Tachibana S, et al. Undifferentiated carcinoma with osteoclast-like giant cells arising in a mucinous cystic neoplasm of the pancreas. Pathol Int. 2008;58:383-389.

18. Wada T, Itano O, Oshima G, et al. A male case of an undifferentiated carcinoma with osteoclast-like giant cells originating in an indeterminate mucin-producing cystic neoplasm of the pancreas. A case report and review of the literature. World J Surg Oncol. 2011; 9:100.

19. Carvounis EE, Smyrniotis V, Chatziioannou A, et al. Undifferentiated carcinoma with osteoclast-like giant cells of the pancreas. Int J Gastrointest Cancer. 2003;33:103-106.

20. Moore JC, Bentz JS, Hilden K, et al. Osteoclastic and pleomorphic giant cell tumors of the pancreas: a review of clinical, endoscopic, and pathologic features. World J Gastrointest Endosc. 2010;2:15-19.

21. Machado MAC, Herman P, Montagnini AL, et al. Benign variant of osteoclast-type giant cell tumor of the pancreas: importance of the lack of epithelial differentiation. Pancreas. 2001;22:105-107.

22. Mercer M, Mccabe MM, Murphy JJ. Recurrence of osteoclast-like giant cell carcinoma of the pancreas after 10 years. Aust N Z J Surg. 1996;66: 334-335.

23. Thadani A, Pais S, Savino J. Metastasis of renal cell carcinoma to the pancreas 13 years postnephrectomy. Gastroenterol Hepatol (N Y). 2011 7:697-699.

24. Morohoshi T, Heitz P. Immunocytochemical markers of uncommon pancreatic tumors. Cancer. 1987;59.

25. Pettinato G, Manivel JC, Ravetto C, et al. Papillary cystic tumor of the pancreas. A clinicopathologic study of 20 cases with cytologic, immunohistochemical, ultrastructural, and flow cytometric observations, and a review of the literature. Anat Pathol. 1991. https:// academic.oup.com/ajcp/article-abstract/98/5/478/1806236. Accessed July 23,2018

26. Zamboni G, Pea M, Martignoni G, et al. Clear cell "sugar" tumor of the pancreas: a novel member of the family of lesions characterized by the presence of perivascular epithelioid cells. Am J Surg Pathol. 1996; 20:722-730.

27. Sasaki A, Ishio T, Bandoh T, et al. Clear cell carcinoma of the pancreas: an adenocarcinoma with unusual phenotype of duct cell origin. J Hepatobiliary Pancreat Surg. 2004;11:140-144.

28. Kim L, Liao J, Zhang M, et al. Clear cell carcinoma of the pancreas: histopathologic features and a unique biomarker: hepatocyte nuclear factor-1 $\beta$. Mod Pathol. 2008:21:1075-1083.

29. Lüttges J, Vogel I, Menke M, et al. Clear cell carcinoma of the pancreas: an adenocarcinoma with ductal phenotype. Histopathology. 1998;32: 444-448.

30. Lee H-Y, Lee D-G, Chun K, et al. clear cell carcinoma of the pancreasa case report and review of the literature. Cancer Res Treat. 2009; 41:175.

31. Kanai N, Nagaki S, Tanaka T. Clear cell carcinoma of the pancreas. Acta Pathol Jpn. 1987;37:1521-1526.

32. Batoroev YK, Nguyen GK. Clear-cell carcinoma of the pancreas in fineneedle aspirate. Diagn Cytopathol. 2005;32:249-251.

33. Cubilla AL, Fitzgerald PJ. Cancer of the pancreas (nonendocrine): a suggested morphologic classification. Semin Oncol. 1980;6: 285-297.

34. Urbanski S, Medline A. Giant cell carcinoma of pancreas with clear cell pattern in metastases. Hum Pathol. 1982;13:1047-1049.

35. Ray S, Lu Z, Rajendiran S. Clear cell ductal adenocarcinoma of pancreas. Arch Pathol Lab Med. 2004;128:693-696. 
36. Jamali M, Serra S, Chetty R. Adenosquamous carcinoma of the pancreas with clear cell and rhabdoid components. A case report. J Pancreas. 2007;8:330-334.

37. Modi Y, Shaaban H, Gauchan D, et al. Primary clear cell ductal adenocarcinoma of the pancreas: a case report and clinicopathologic literature review. J Cancer Res Ther. 2014:10:773-776.

38. Sun P-J, Yu Y-H, Cui X-J. Primary clear cell adenocarcinoma of the pancreas: a case report and literature update. Onco Targets Ther. 2018: 8197-8200.

Cite this article as: Hanayneh W, Parekh $\mathrm{H}$, Fitzpatrick G, Feely M, George TJ, Jr, Starr JS (2019) Two cases of rare pancreatic malignancies, Journal of Pancreatic Cancer 5:1, 26-33, DOI: 10.1089/pancan.2019.0007.

\section{Abbreviations Used}

CA 19-9 = carbohydrate antigen 19-9

$\mathrm{CEA}=$ carcinoembryonic antigen

$\mathrm{CT}=$ computed tomography

EUS = endoscopic ultrasonography

$\mathrm{FNA}=$ fine needle aspiration

$\mathrm{GCT}=$ giant cell tumor

$\mathrm{IHC}=$ immunohistochemistry

$\mathrm{MCN}=$ mucinous cystic neoplasm

$\mathrm{MRI}=$ magnetic resonance image

PDAC $=$ pancreatic ductal adenocarcinoma

UCOGC $=$ undifferentiated carcinoma with osteoclast-like giant cells

WHO $=$ World Health Organization

\section{Publish in Journal of Pancreatic Cancer}

- Immediate, unrestricted online access

- Rigorous peer review

- Compliance with open access mandates

- Authors retain copyright

- Highly indexed

- Targeted email marketing

liebertpub.com/pancan 